\title{
PENERAPAN METODE PETA PIKIRAN DALAM MENULIS ESAI MAHASISWA SEMESTER V STKIP YDB LUBUK ALUNG
}

\author{
Irawati Rahman dan Dwi Mutia Chan \\ Program Studi Pendidikan Bahasa dan Sastra Indonesia STKIP YDB Lubuk Alung \\ Korespondensi: J1. Pulau Jantung Indah No.91 Pasar Mudik Lubuk Alung, Kab. Padang Pariaman \\ e-mail: rahmanirawati40@yahoo.com
}

\begin{abstract}
This research is based on several problems found in students' writing; (1) the structure of students' essay is not complete; (2) the use of languge is not communicative; (3) the paragraph development is not coherent; and (4) the title of the essay is not appropriate. This reseach aims at implementing mind mapping technique in writing an essay. Mind mapping is a technique of teaching writing to help students map their idea in writing an essay. This research used quantitative research. The research sample was the fifth semester students of STKIP YBD Lubuk Alung registered in 2015/2016 academic year. The result of this research shows that mind mapping technique could increase students' writing. This is indicated by the increase of students' score after applying mind mapping technique. 25 students (92.6\%) got very good score and 2 others (7.43\%) got good score. Based on this finding, it is suggested for English teachers to use mind mapping technique to improve students' writing skill.
\end{abstract}

Kata Kunci: penerapan, teknik mind mapping, keterampilan menulis esai

\section{PENDAHULUAN}

$\mathrm{K}$

egiatan pokok dalam pembelajaran menulis adalah membangkan gagasan dan menuangkan gabangkan gagasan dan menuangkan gagasan itu dalam berbagai jenis karangan seperti narasi, deskripsi, argumentasi, eksposisi dan persuasi. Keterampilan menulis merupakan keterampilan yang tidak mudah. Keterampilan ini menuntut kemampuan seseorang untuk menuangkan ide, gagasan, pikiran, dan perasaan untuk menjadi karya sehingga orang lain dapat memahami karya tersebut.

Keterampilan yang diperlukan mahasiswa di perguruan tinggi juga didominasi oleh aktivitas menulis. Aktivitas menulis itu tidak hanya dalam bentuk karangan ilmiah seperti makalah, tetapi juga seperti menulis esai dan bentuk karangan yang lain. Melalui aktivitas menulis, mahasiswa dapat mengembangkan gagasan, mengungkapkan sesuatu secara tertulis dan membiasakannya bernalar. Dengan demikian, kegiatan menulis dilakukan untuk membantu mahasiswa mencapai tujuan belajar di perguruan tinggi, yakni membangun daya berpiki

$\mathrm{r}$ kritis dan daya nalar yang tinggi. Mahasiswa harus dapat mencari informasi untuk diolah dan diaplikasikan dalam bentuk karang-an seperti esai.

Ketidakmampuan dalam berbahasa, khususnya dalam menulis esai juga dialami oleh mahasiswa STKIP YDB Lubuk Alung. Hal itu terlihat dari kesulitan mahasiswa menuangkan gagasan dalam kalimat-kalimat untuk memulai kalimat pertama sehingga 
banyak waktu terserap untuk memulai tulisan karena mereka tidak tahu harus memulai dari mana. Selain itu, dosen pembina mata kuliah tidak mengembangkan metode pembelajaran yang menarik bagi mahasiswa. Pada umumnya dosen tidak dipersiapkan untuk terampil menulis dan mengajar. Dosen kurang membimbing siswa untuk memikirkan apa yang akan ditulis dan bagaimana menuangkan pemikiran dalam bentuk tertulis. Proses menulis belum dilaksanakan secara sistematis dan belum mengoptimalkan kemampuan mahasiswa. Program yang dirancang dosen pada silabus berpedoman pada aspek-aspek yang perlu dikerjakan mahasiswa dalam setiap tahap menulis. Kegiatan yang dilakukan di kelas belum dapat mengoptimalkan kemampuan mahasiswa dalam menulis.

Adapun permasalahan dan fenomena yang terjadi di lingkungan Program Studi PBI STKIP YDB Lubuk Alung yang sangat mendasar, yaitu rendahnya semangat dan motivasi mahasiswa dalam menulis, khususnya pada pembelajaran menulis esai dalam mata kuliah menulis kreatif. Mahasiswa tidak terlatih dalam menulis esai. Hal itu terlihat dari hasil tes yang diadakan. Mahasiswa kesulitan menemukan dan memilih topik yang hendak disampaikan dan mereka tidak membiasakan menulis dengan membuat kerangka karangan (outline). Oleh sebab itu, mereka juga kesulitan menemukan ide pokok esai. Mahasiswa kesulitan memberi ilustrasi yang segar dan menarik yang disebabkan karena keterbatasan penguasaan kosa kata yang dimiliki mahasiswa dan pemilihan diksi yang tidak tepat sehingga tugas esai yang mereka hasilkan tidak menarik. Selain itu mahasiswa juga tidak dapat menutup tulisan dengan paragraf yang kuat, karena tidak ada penekanan khusus, ajakan, ataupun sindiran pada bagian akhir esai. Selanjutnya mahasiswa juga belum dapat menyunting tulisan secara teliti. Sehingga hasil tulisan esai menjadi tidak menarik.

\section{LANDASAN TEORI}

Keterampilan menulis meliputi berbagai aspek kemampuan yang saling terkait dan perlu dikuasai untuk dapat menghasilkan suatu tulisan. Untuk dapat dipahami dan diterima dengan baik oleh pembaca, pengungkapan gagasan melalui karangan menuntut sejumlah kemampuan dan keterampilan. Menulis bukan hanya sekedar menggambar huruf atau menyalin, namun menulis sebagai aspek keterampilan berbahasa adalah keterampilan mengemukakan pikiran, keterampilan menyampaikan perasaan melalui bahasa tulis.

Menurut Atmazaki (2006: 109), esai diartikan sebagai karangan prosa yang berisi pandangan, pendapat, perasaan, dan pikiran sejauh suatu masalah mengugah pikiran pengarang. Apabila sudah mampu menulis esai singkat dengan baik, maka menulis esai panjang hanya memerlukan tambahan bahan. Apabila bahan sudah ada, memperpanjang esai bukan perkara mudah. Menurut Budiman (dalam Thahar 2008: 145) esai adalah karangan yang sedang panjangnya, biasanya dalam bentuk prosa, yang mempersoalkan suatu persoalan secara mudah dan sepintas lalu tepatnya mempersoalkan suatu persolan tersebut merangsang hati penulisnya.

Pada dasarnya struktur esai terdiri atas pendahuluan, pembahasan, dan simpulan. Berikut merupakan sebuah diagram garis besar struktur esai lima paragraf menurut Atmazaki (2006: 113114).

I. Pendahuluan (Paragraf 1)

1. Pembukaan (generalisasi, pertanyaan, anekdot)

2. Penjelasan Pembuka, menuju ke Pernyataan Tesis 
3. Pernyataan Tesis (nama, judul, peristiwa, argument umum, tiga alasan mengapa argumen Anda benar)

II. Pembahasan (Paragraf 2)

4. Kalimat Pembuka (yang menyinggung tema 1)

5. Penjelasan

6. Bukti A

7. Penjelasan tentang bukti A

8. Kesimpulan-mini hanya tentang Tema 1

III. Pembahasan (Paragraf 3)

9. Kalimat Pembuka (yang menyinggung Tema 2)

10. Penjelasan

11. Bukti B

12. Penjelasan tentang bukti B

13. Kesimpulan mini hanya tentang Tema 2

IV. Pembahasan (Paragraf 4)

14. Kalimat Pembuka (yang menyinggung Tema 3 )

15. Penjelasan

16. Bukti C

17. Penjelasan tentang bukti $\mathrm{C}$

18. Kesimpulan mini hanya tentang Tema 3

V. Kesimpulan (Paragraf 5)

19. Kalimat transisi yang mengikat esai (kembali ke anekdot/kutipan/generalisasi)

20. Konfirmasi kembali argumen Anda, jelaskan bagaimana Anda membuktikannya (tulis tesis kecil, di sini diperlukan pernyataan yang tegas)

21. Kemungkinan munculnya ide baru yang terkait dengan tesis Anda (tidak harus)

Peta pikiran adalah alternatif pemikiran keseluruhan otak terhadap pemikiran linear. Mind map menggapai ke segala arah dan menangkap berbagai pikiran dari segala sudut (Michael Michalko dalam Tony Buzan, 2007). Senada dengan pendapat tersebut, Tony Buzan (2007: 103) mengungkapkan bahwa mind map adalah alat berpikir kreatif yang mencerminkan cara kerja alami otak. Peta pikiran memungkinkan otak menggunakan semua gambar dan asosiasinya dalam pola radial dan jaringan sebagaimana otak dirancang seperti yang secara internal selalu digunakan otak.

Mind map merupakan cara termudah untuk menempatkan informasi ke dalam otak dan mengambil informasi ke luar dari otak. Mind map adalah cara mencatat yang kreatif, efektif, dan secara harfiah akan "memetakan" pikiranpikiran (Buzan, 2007: 4). Mind map bisa dibandingkan dengan peta kota. Bagian tengah mind map sama halnya dengan pusat kota dan mewakili gagasan terpenting; jalan-jalan protokol yang memancar keluar dari pusat kota merupakan pikiran-pikiran utama dalam proses berpikir, jalan-jalan atau cabang-cabang sekunder merupakan pikiran sekunder (Buzan, 2004: 6).

Buzan (2005: 15) mengemuka-kan tujuh langkah untuk membuat peta pikiran. Tujuh langkah tersebut adalah sebagai berikut: (1) mulailah dari bagian tengah kertas kosong yang sisi panjangnya diletakkan mendatar, (2) gunakan gambar atau foto untuk ide sentral, (3) gunakan warna, (4) hubungkan cabangcabang utama ke gambar pusat dan hubungkan cabang-cabang tingkat dua dan tiga ke tingkat satu dan dua, dan seterusnya. Otak senang mengaitkan dua (atau tiga atau empat) hal sekaligus. Bila cabang-cabang dihubungkan akan lebih mudah dimengerti dan diingat. (5) buatlah garis hubung yang melengkung, bukan garis lurus. Cabang-cabang yang melengkung dan organisasi seperti cabang-cabang pohon jauh lebih menarik bagi mata. (6) gunakan satu kata kunci untuk setiap garis agar dapa memberi lebih banyak daya dan fleksibilitas kepada peta pikiran. (7) gunakan gambar. 


\section{METODOLOGI PENELITIAN}

Penelitian ini termasuk jenis penelitian kuantitatif dengan menggunakan metode deskriptif. Arikunto (2010: 10) mengemukakan "suatu penelitian dikatakan kuantitatif karena banyak menggunakan angka, mulai dari pengumpulan data, penafsiran terhadap data tersebut, dam penampilan hasilnya". Metode deskriptif dalam penelitian ini digunakan untuk mendeskripsikan keterampilan menulis esai dengan metode peta pikiran mahasiswa STKIP YDB Lubuk Alung . sampel penelitian ini adalah mahasiswa semester V STKIP YDB Lubuk Alung sebanyak 27 orang.

Variabel penelitian ini adalah keterampilan menulis esai mahasiswa STKIP YDB Lubuk Alung. Data penelitian ini adalah hasil tes keterampilan menulis esai mahasiswa STKIP YDB Lubuk Alung. Teknik pengumpulan data sebagai berikut. Data dikumpulkan dengan cara memberikan tes dalam bentuk tes unjuk kerja menulis esai kepada mahasiswa yang dijadikan sampel penelitian.

Analisis data pada penelitian ini terdiri dari lima langkah penilaian sebagai berikut: (a)Pemberian nilai untuk setiap aspek dilakukan dengan memberikan tanda cek $(\sqrt{ })$ pada kolom skala nilai yang dianggap cocok (Abdurrahman dan Ratna, 2003: 111). Masing-masing skala pada lembar penilaian diberikan makna, yaitu (1) skala 1 = sangat tidak baik, (2) skala $2=$ tidak baik, (3) skala 3 = agak baik, (4) skala $4=$ baik, (5) skala $5=$ sangat baik . Memperhatikan deskripsi setiap skala penilaian sebelum dan selama penilaian berlangsung. Nilai yang diperoleh oleh masing-masing mahasiswa didapat dari hasil penjumlahan skor setiap aspek yang dinilai dibagi dengan jumlah skor maksimum (Sudjana 2006: 133). Untuk nilai dengan standar 100, angka hasil pembagian tadi dikali dengan 100 . langkah ini dapat dituliskan sebagai berikut:

Nilai perolehan $=\sum$ skor perolehan $X$ 100

$$
\sum \text { skor maksimal }
$$

Selanjutnya, data hasil penilaian yang telah dianalisis tersebut dideskripsikan untuk menjelaskan makna dari skor yang diperoleh oleh mahasiswa pada masing-masing aspek secara klasikal. Membuat kesimpulan hasil penilaian dengan menginterprestasikan data tersebut dengan teori yang relevan dalam laporan hasil penelitian.

\section{HASIL DAN PEMBAHASAN}

Pelaksanaan pembelajaran dengan menjelaskan teori dan konsep esai, menjelaskan peta pikiran, langkah-langkah pembuatan peta pikiran, dan menjelaskan topik yang akan ditulis menjadi esai dengan menggunakan peta pikiran. Berikutnya penyusunan draf esai dengan membuat peta pikiran mulai dari tingkat batang, cabang, dan ranting dengan menggunakan pensil warna. Pembuatan peta pikiran ini dengan mempertimbangkan ketepatan penggunaan kata kunci, penggunaan cabang, pemilihan warna dan penggunaan gambar. Pertemuan berikutnya dengan materi menulis esai dengan mempertimbangkan struktur esai, pemilihan judul, pengembangan paragraf, dan kalimat efektif.

Dosen memberikan penjelasan singkat mengenai esai dan peta pikiran beserta contohnya. Dosen menyediakan model peta pikiran yang akan dicermati yang akan dijadikan inspirasi bagi mahasiswa dan beberapa mahasiswa secara bergantian memberi pandangan tentang esai lima paragraf. Dosen memberikan kesempatan kepada mahasiswa untuk menanggapi permasalahan yang dikemukakan oleh temannya. Mahasiswa berdiskusi secara klasikal berdasarkan arahan dari dosen. Dosen menjelaskan 
bahwa pandangan-pandangan yang berbeda tersebut jika ditulis akan menjadi sebuah esai. Pada kegiatan ini, perhatian mahasiswa terhadap materi yang disampaikan cukup serius.

Selanjutnya, dosen mengarahkan mahasiswa untuk membentuk lima kelompok yang terdiri dari 6-7 orang. Setiap kelompok diminta untuk menentukan permasalahan yang akan dijadikan ide sentral pada peta pikiran. Dalam kelompoknya masing-masing, mahasiswa mendiskusikan permasalahan yang akan dijadikan ide sentral pada peta pikiran. Dosen mengarahkan mahasiswa untuk membuat peta pikiran sesuai dengan ide sentral yang sudah ditentukan. Masing-masing kelompok membuat satu peta pikiran sesuai dengan ide sentral yang sudah ditentukan. Masing-masing kelompok membuat satu peta pikiran melalui bimbingan dari dosen. Mahasiswa tampak cukup antusias dalam mengerjakan tugas yang akan diberikan. Kemudian dosen mengembalikan tugas kelompok tentang membuat peta pikiran yang sudah dikoreksi dan diberi saran perbaikan. Dosen mengarahkan masingmasing mahasiswa menulis artikel populer dengan peta pikiran yang telah dikembalikan. Melalui bimbingan dosen, masing-masing mahasiswa menulis esai dengan mengacu kepada peta pikiran yang dibuat kelompok. Ketika jam perkuliahan selesai, mahasiswa diminta mengumpulkan esai untuk dikoreksi oleh dosen.

Dari empat indikator yang dinilai struktur esai memperoleh skor tertinggi yaitu 92 dengan rata-rata 3,40. Kriteria kedua pemilihan judul memperoleh skor sebesar 88 dengan rata-rata 3,26. Kriteria pengembangan paragraf memperoleh skor sebesar 74 dengan rata-rata 2,74. Kriteria kalimat efektif memperoleh skor terendah sebesar 73 dengan rata-rata 2,70. Hasil analisis tes unjuk kerja menulis esai lima paragraf berpengaruh terhadap skor yang diperoleh mahasiswa dalam meulis esai lima paragraf. Semua nilai mahasiswa sudah sesuai dengan target yang diharapkan. Mahasiswa yang mendapatkan nilai A sebanyak 25 orang atau $(92,6 \%)$, dan mahasiswa yang mendapatkan nilai $\mathrm{B}$ hanya 2 orang atau $(7,4 \%)$ diperoleh rata-rata kelas sebesar 845,29 . Hal ini menggambarkan bahwa pembelajaran menulis esai lima paragraf sudah mendapat nilai bak semuanya. Meskipun peningkatan tersebut tidak terlalu tinggi, secara merata mahasiswa sudah menguasai materi tentang esai.

\section{PENUTUP}

Berdasarkan analisis data dapat disimpulkan penerapan metode peta pikiran berpengaruh terhadap keterampilan menulis esai lima paragraf mahasiswa semester V kelas C STKIP Dharma Bakti Lubuk Alung. Artinya dengan menggunakan metode peta pikiran, maka mahasiswa akan lebih terarah dalam menulis. Dengan adanya peta pikiran yang dibuat secara berkelompok ternyata dapat meningkatkan keterampilan mahasiswa dalam menulis esai lima paragraf. Hal ini terbukti dalam penelitian yang telah dilakukan di kelas C STKIP Dharma Bakti Lubuk Alung. Bahwa dengan dilakukan diskusi dan pembuatan peta pikiran sebelum menulis esai oleh mahasiswa ternyata dapat meningkatkan keterampilan mahasiswa dalam menulis esai lima paragraf. Jika dibandingkan dengan cara pembelajaran bercerita atau memberikan penjelasan semata. Diadakannya diskusi dan peta pikiran terlebih dahulu mengarahkan pembelajaran ke arah yang lebih konkret (nyata) dari pada pembelajaranya yang masih abstrak.

Berdasarkan hasil penelitian disarankan sebagai berikut: (1) Kepada dosen, metode peta pikiran dapat dijadikan sebagai alternatif pilihan model pembelajaran keterampilan menulis, khususnya pembelajaran keterampilan 
menulis esai lima paragraf. (2) Kepada peneliti, selanjutnya diharapkan menggunakan metode peta pikiran pada subjek penelitian yang lain dengan alat

\section{DAFTAR RUJUKAN}

Alwasilah, Chaedar dan Senny Alwasilah. 2007. Pokoknya Menulis. Bandung: Kiblat Buku Utama.

Arikunto, Suharsimi, dkk. 2006. Penelitian Tindakan Kelas. Jakarta: Bumi Aksara.

Atmazaki. 2006. Kiat-kiat Mengarang dan Menyunting. Padang: Citra Budaya.

Semi, M. Atar. 2009. Menulis Efektif. Padang: Angkasa Raya.

Slavin, Robert. 2009. Cooperative Learning: Teori, Riset, dan Praktik. Bandung: Nusa Media. pengumpulan data yang lengkap dan memadai agar gambaran hasil penelitian yang luas dan sempurna dapat diperoleh pembaca.

Sudjino, Anas. 1997. Pengantar Statistik Pendidikan. Jakarta: Raja Grafindo Persada.

Sugiyono. 2008. Metode Penelitian Kualitatif dan Kuantitatif dan $R$ \& $D$. Bandung: Alfabeta.

Atmazaki. 2006. Kiat-kiat Mengarang dan Menyunting. Padang: Citra Budaya.

Buzan, Tony. 2007. Mind Map. Jakarta: Gramedia Pustaka Utama.

Depdiknas. 2004. Materi Pelatihan Terintegrasi Buku 3. Jakarta: Depdiknas. 